\title{
Computer simulation of power balance of a solar vehicle depending on its parameters and outside factors
}

\author{
G. Frydrychowicz-Jastrzębska ${ }^{1}$, E. Perez Gomez ${ }^{2}$ \\ ${ }^{1}$ Poznań University of Technology \\ Institute of Industrial Electrical and Electronical Engineering \\ Piotrowo Street 3a, 60-965 Poznań (Poland) \\ e-mail: grazyna.jastrzebska@put.poznan.pl \\ Phone, +48 616652388, fax, +48616652389 \\ ${ }^{2}$ Universidad de Politecnica de Cartagena \\ 30202 Cartagena, Plaza del Cronista Isidoro Valverde - Edificio La Milagrosa (Spain) \\ e-mail: sinuhedu@hotmail.com
}

\begin{abstract}
The paper presents simulation of steady motion of a solar vehicle supplied with solar energy directly from a panel and indirectly from a battery. Analysis of power distribution has been carried out, inclusive of the power demand related to the need of overcoming rolling and aerodynamic resistance with respect to its structural and operational parameters and parasite losses and with regard to geographic location, hourly distribution of insolation on recommended days of selected months, spatial arrangement of the panel, aided by an accumulator battery.
\end{abstract}

\section{Key words}

solar power, photovoltaic panel, battery charge, solar car, Trans - Australian World Solar Challenge Race.

\section{Introduction}

Solar cars are reckoned as automotive vehicles driven by electric energy obtained as a result of photovoltaic conversion $[2,5,6,7,9,13]$ In order to use the module as a power source a power accumulator should be connected to it $[2,3,5,12]$.

Low power consumption is very important in case of solar vehicles Therefore, they should be characterized with low mass, low value of the rolling resistance coefficient, and - aerodynamic shape $[2,7,9,13]$ that is shown in Fig.1.

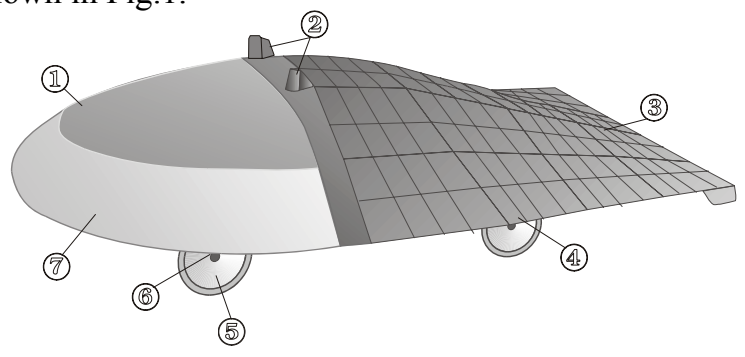

Fig.1. Solar car "Sunraycer", plexiglass windscreen covered with gold (1), stabilizers (2), solar batteries (3), rear drive (4), plastic wheels discs (5), body reinforcement (kevlar) (6) [9]

The requirements imposed on the vehicles supplied with solar energy include among others $[1,2,3,5,6,7,8,9$, 13]:

- monoposte composite car body optimized to light weight and little air resistance, Table 2,
- construction form supporting fiber reinforced body structure, a shell of body on layer lamination, strengthening ribs in sandwich construction (a little aerodynamic coefficient),

- special solar car tires with a little coefficient rolling resistance,

- solar generator - highly efficient solar cells (Table 2), enclosed in ultra- lightweight glass - fiber reinforced plastic,

- highly efficient solar Maximum Power Point Tracker $(98-99 \%),[3,9,10,11]$.

- synchro - motor with magneto - pernament, efficiency $95-98 \%$ [13],

- battery with highly efficient and capacity (li-ion, lipolymer, zinc-air), 80 - $95 \%$ [13],

- instrument of panel and drive units controls $97 \%$ [8].

\section{Participans of Solar Challenge Race}

Twenty four entries from the seven countries cited starting in the Trans - Australian World Solar Challenge Race in year 1987. The winner, Sunraycer, shown in Fig.1. is a solar car designed in 1987 by General Motors. This is a one - seat and four - wheeled car. Sunraycer built on an aluminium tube space - frame (weight with a driver ballasted $248 \mathrm{~kg}$ ) [13]. It won the Trans-Australia World Solar Challenge Race, travelling the route with the velocity of $70 \mathrm{~km} / \mathrm{h}[9,13]$. In this vehicle the monoctrystalline silicon solar cells have been used, with an electric motor of $1,5 \mathrm{~kW}$, and silver-zinc batteries.

Figs. 2, 3, and 4 shows solar cars - which took part in Trans-Australia World Solar Challenge Race, in year 1999. Only 28 of vehicles out of 40 starting in this have finished the race [13].

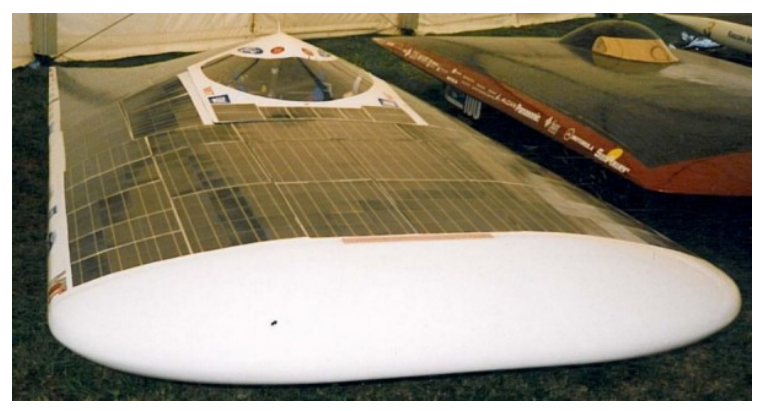

Fig.2. Solar car Manta GTX, 8-th plays [9] 


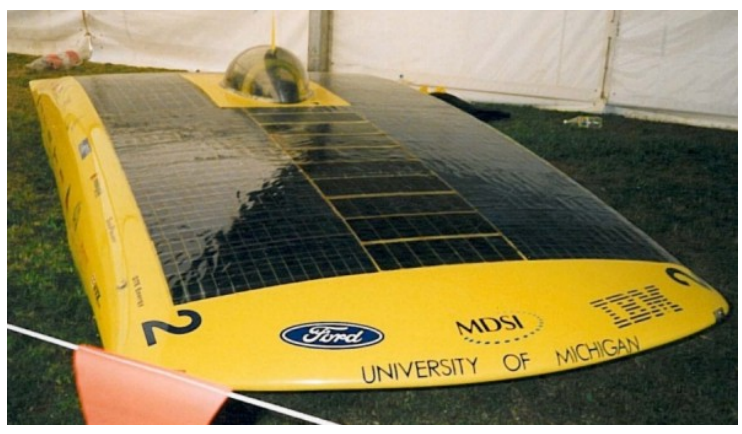

Fig.3. Solar car Maize Blaize, 9-th plays [9]

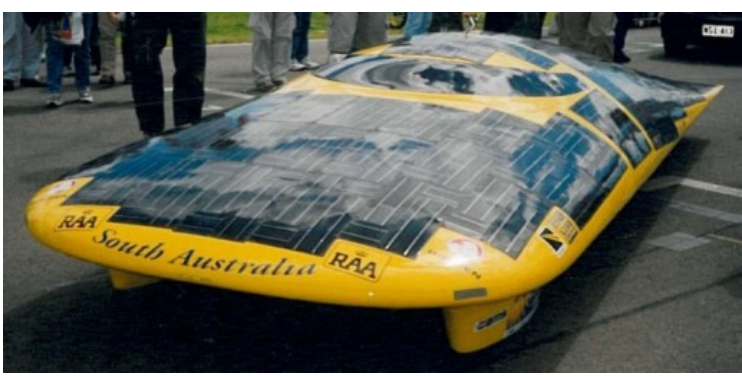

Fig.4. Solar car NED 14-th plays [9]

The vehicle named Sky Ace Tiga designed by students of Ashiya University won the Australian Race World Solar Challenge in 2006, achieving the velocity of $165 \mathrm{~km} / \mathrm{h}$ [14].

It has been provided with gallium arsenide solar cells, electric motor of $1,5 \mathrm{~kW}$, and ionic-polymer batteries [8, $9,13]$.

\section{Basic relationships}

A. The rolling and aerodynamic resistance of the solar car

The total power that should be supplied to the wheels consists following components:

- the power required for overcoming the rolling resistance [2]:

$$
P_{R}=0,278 c_{T}\left(1+\frac{v}{161}\right) G v
$$

- the power required for overcoming the aerodynamic resistance [2]:

$$
P_{A}=0,0125 v^{3} A c_{A}
$$

where: $G$ - the vehicle weight, $v$ - the vehicle speed, $c_{T}$ the rolling resistance coefficient, $c_{A}$ - the aerodynamic vehicle coefficient, $A$ - total front surface of the vehicle. - parasite losses $30 \mathrm{~W}$ [2].

The power required for overcoming the rolling resistance depends also on the vehicle and driver mass and the vehicle speed.

The vehicle participating in the solar races have the rolling coefficients of $\mathrm{c}_{\mathrm{T}}=0,0040$ (Honda Dream) $\div$
0,0055 (Biel III). In case of using of special tyres the rolling coefficient may be reduced to $\mathrm{c}_{\mathrm{T}}=0,0020$ [13].

The air resistance force becomes more important for the speed exceeding $50 \mathrm{~km} / \mathrm{h}$ and predominates for the speed higher than $100 \mathrm{~km} / \mathrm{h}$. The aerodynamic resistance is a function of a front surface, vehicle shape, smoothness of the surface, and vehicle speed [5]. The aerodynamic resistance coefficient takes the value $c_{A}=0,1$ (Honda Dream, Biel III) [13], front surface of the vehicle takes value $A=1 \div 1,2$.

The total power [2]:

$$
P_{T}=\frac{P_{R}+P_{A}}{\eta}+30 W
$$

\section{B. The energy obtained from the photovoltaic conversion}

Based on the PVGIS data and the relationships provided by [6] and taking into account the panel surface area and the material (conversion efficiency) the power obtained by the PV conversion has been determined by the equation [2]:

$$
P_{B S}=P_{\max } \cos \theta[\cos (\Phi)]^{0,3}
$$

where: $\mathrm{P}_{\max }-$ is the maximal power the array produces when aligned with the sun, $\theta$ the angle between the plane normal to the photocell surface and the direction of solar radiation incident thereon, $\Phi$ the solar angle (the angle between the sunlight and normal to the ground). The solar angle is indirectly a function of the declination angle, hour angle, latitude, at the angle of the receiver inclination with regard to the Earth surface [2, 3, 5, 11]. While the vehicle is in motion, the panel surface is parallel to the ground $(\theta=\Phi)$ and the feasible power obtained from a PV battery is as follows $[2,6]$ :

$$
P_{\text {motion }}=P_{\text {max }}[\cos (\Phi)]^{1,3}
$$

On the other hand, when the vehicle is immobile, the panel is optimally arranged, i.e. perpendicularly to solar radiation, and the equation describing the power is $[2,5]$ :

$$
P_{\text {Bimmobile }}=P_{\text {max }}[\cos (\Phi)]^{0,3}
$$

Electric energy obtained from the PV panel can be used to charge driving systems $[2,10,11,13]$.

\section{Complementing power acquired from accumulator battery}

Since the panel power in some time intervals is subject to important changes, arises a need of complementing the vehicle supply from an accumulator. In the simulation based on Peukert's model [9] the required complementing power from accumulator has been determined. The Peukert model for the battery capacity is as follows $[2,5]$ : 


$$
C_{A k k}=\frac{C}{p^{(p-1)}}
$$

where: $\mathrm{C}-\mathrm{a}$ constant determining the power efficiency of the accumulator battery, $\mathrm{p}$ - the Peukert constant (Table 2)..

The accumulator unloading level has been determined too.

Fig. 5. shows the power balance in solar car.

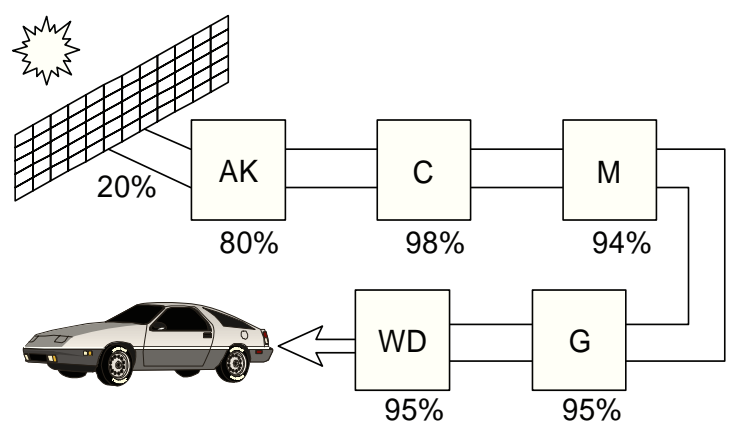

Fig. 5. The power balance in solar car

\section{Conditions of the computer simulation}

A case of steady motion of a solar vehicle supplied with solar energy gained from photovoltaic conversion. The vehicle starts at 8 a.m. with a full charge battery. The simulation has been made for the speed range from 40 to $140 \mathrm{~km} / \mathrm{h}$. In the time of higher insolation or with lower resistance to motion the battery charge is equalized during the travel. In case of battery discharged below the allowable level the vehicle should stop in order to enable optimal arranging of the panel and recharging the battery with solar energy.

The simulation takes into account geographical location of Barcelona $(41,4)$ and Warsaw $(52)$ as well as hourly distribution of radiation power density on the recommended days, from PVGIS database (Table 1).

Table 1. Irradiance in Barcelona and Warsaw in June and August

\begin{tabular}{|c|c|c|c|c|}
\hline \multirow{2}{*}{ Hour } & \multicolumn{2}{|c|}{ Barcelona } & \multicolumn{2}{c|}{ Warszawa } \\
\cline { 2 - 5 } & June & August & June & August \\
\hline 4.07 & 0 & 0 & 59 & 0 \\
\hline 4.22 & 0 & 0 & 96 & 0 \\
\hline 4.37 & 0 & 0 & 136 & 0 \\
\hline 4.52 & 126 & 0 & 173 & 0 \\
\hline 5.07 & 211 & 0 & 207 & 66 \\
\hline 5.22 & 280 & 0 & 239 & 114 \\
\hline 5.37 & 342 & 188 & 269 & 164 \\
\hline 5.52 & 398 & 275 & 297 & 210 \\
\hline$\ldots \ldots \ldots$. & $\ldots \ldots \ldots$. & $\ldots \ldots \ldots$ & $\ldots \ldots \ldots$. & $\ldots \ldots \ldots$. \\
\hline 18.22 & 342 & 188 & 269 & 164 \\
\hline 18.37 & 280 & 14 & 239 & 114 \\
\hline 18.52 & 211 & 0 & 207 & 66 \\
\hline 19.07 & 126 & 0 & 173 & 7 \\
\hline 19.22 & 10 & 0 & 136 & 0 \\
\hline 19.37 & 0 & 0 & 96 & 0 \\
\hline 19.52 & 0 & 0 & 59 & 0 \\
\hline 20.07 & 0 & 0 & 8 & 0 \\
\hline
\end{tabular}

Simulation is carried out for the vehicles of various design parameters and operation requirements [2, 5].
Photovoltaic panels of various material parameters have been assumed (Table 2) [9].

Table 2 The ranges of the parameters assumed for simulation purpose

\begin{tabular}{|c|c|c|c|}
\hline \multicolumn{3}{|c|}{ Parameter } & Value \\
\hline \multicolumn{4}{|c|}{ Solar car } \\
\hline \multicolumn{2}{|r|}{ car mass } & {$[\mathrm{kg}]$} & $270-330$ \\
\hline \multirow{3}{*}{$\begin{array}{l}\text { rolling } \\
\text { coefficient }\end{array}$} & special solar car tires & - & 0,0025 \\
\hline & bike tirs on asphalt & - & 0,005 \\
\hline & car tires on asphalt & - & 0,0075 \\
\hline \multirow{3}{*}{$\begin{array}{l}\text { aerodyna } \\
\text { mic } \\
\text { resistance }\end{array}$} & low & - & 0,1 \\
\hline & medium & - & 0,15 \\
\hline & high & - & 0,2 \\
\hline \multicolumn{2}{|r|}{ speed } & {$[\mathrm{km} / \mathrm{h}]$} & $40-140$ \\
\hline \multicolumn{4}{|c|}{ PV array surface $8 \mathrm{~m}^{2}$} \\
\hline \multirow{6}{*}{$\begin{array}{l}\text { material } \\
\text { and } \\
\text { efficiency }\end{array}$} & Si mono & - & 0,23 \\
\hline & Si poli & - & 0,18 \\
\hline & Si amorphous & - & 0,12 \\
\hline & $\mathrm{GaAs}$ & - & 0,26 \\
\hline & CIS & - & 0,17 \\
\hline & CdTe & - & 0,16 \\
\hline \multicolumn{4}{|c|}{ Battery } \\
\hline \multirow{2}{*}{ lead acid } & battery capacity & $\mathrm{W} \cdot \mathrm{h}$ & 4500 \\
\hline & Peukert number & - & 1,22 \\
\hline \multirow{2}{*}{ li-ion } & battery capacity & $\mathrm{W} \cdot \mathrm{h}$ & 6000 \\
\hline & Peukert number & - & 1,08 \\
\hline
\end{tabular}

The efficiency of the driving motor amounts to 98 percent and the one of the battery -80 percent.

\section{Results of the computer simulation}

The figures show power balance of the car running with steady motion in Barcelona and in Warsaw. The balance considers the total and solar power demand and from the battery. Current charge condition of the battery has been illustrated.

Figure 6 presents the power balance of a car running on recommended day of June in Barcelona, with power demand amounting to $1252.10 \mathrm{~W}\left(\mathrm{~m}=270 \mathrm{~kg}, \mathrm{c}_{\mathrm{T}}=\right.$ $0.005, \mathrm{~A} \cdot \mathrm{c}_{\mathrm{A}}=0.1$ and $\mathrm{v}=80 \mathrm{~km} / \mathrm{h}$ ) and battery discharge level corresponding to these conditions. The vehicle is provided with a monocrystalline silicon panel and a leadacid battery (Variant I). Between 8:00 a.m. and 5:00 p.m. in Barcelona the car travelled $720 \mathrm{~km}$, with its battery discharged down to 32.71 percent.

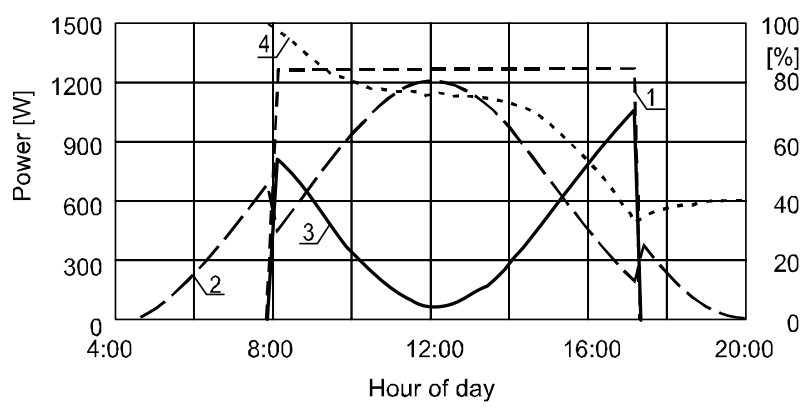

Fig. 6. Power balance of the solar car in Barcelona, Variant I; (1) - power demand; (2) - the power drawn from the panel; (3) - the power drawn from the battery; (4) - total battery discharge 
Figure 7 presents the same graph for Warsaw. On the other hand, in order to overcome the same resistance to motion in Warsaw a higher battery power was required. In result the battery was totally discharged already at 4:00 p.m. The travelled distance amounted to $640 \mathrm{~km}$.

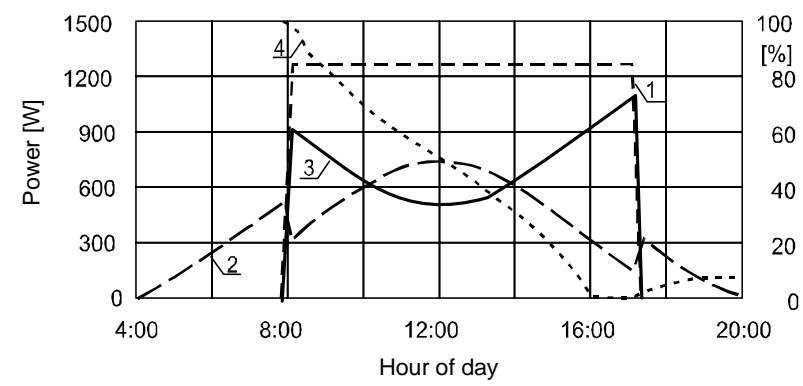

Fig. 7. Power balance of the solar car in Warsaw, Variant I; (1) - power demand; (2) - the power drawn from the panel; (3) the power drawn from the battery; (4) - total battery discharge

In August (Variant II) and the resistance to motion equal to that of Variant I the vehicle stopped in Barcelona after $720 \mathrm{~km}$ on 5:00 p.m. and the battery discharged down to 13.6 percent. In Warsaw the battery was totally discharged at 3:15 p.m. with travelled distance of $580 \mathrm{~km}$ (Figs 8 and 9).

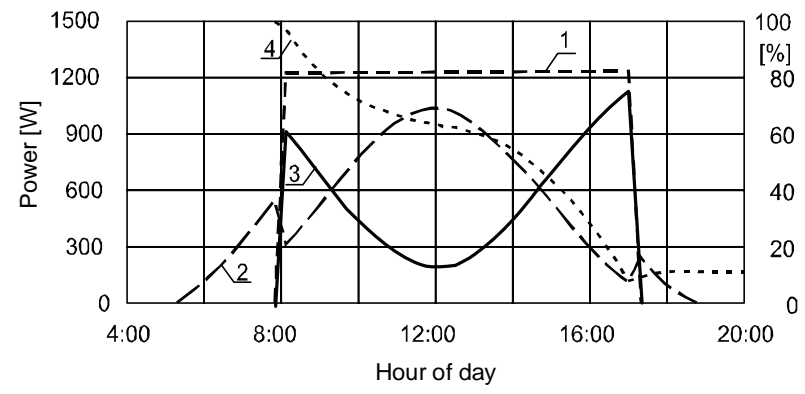

Fig. 8. Power balance of the solar car in Barcelona, Variant II; (1) - power demand; (2) - the power drawn from the panel; (3) - the power drawn from the battery; (4) - total battery discharge

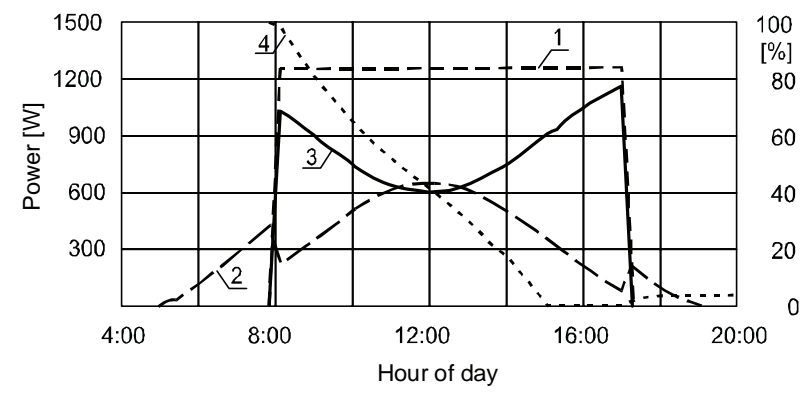

Fig. 9. Power balance of the solar car in Warsaw, Variant II; (1) - power demand; (2) - the power drawn from the panel; (3) the power drawn from the battery; (4) - total battery discharge

For improved design parameters of the vehicle (Variant III, $\left.\mathrm{c}_{\mathrm{T}}=0.0025, \mathrm{~A} \cdot \mathrm{c}_{\mathrm{A}}=0.1, \mathrm{~m}=270 \mathrm{~kg}, \mathrm{v}=60 \mathrm{~km} / \mathrm{h}\right)$ and its speed reduced to $60 \mathrm{~km} / \mathrm{h}$ (the total demand is 506.68 $\mathrm{W})$ and the range grows accordingly - Figs 10 and 11. In Barcelona in June, the panel power covers the demand and the power surplus charges the battery. In the time from 10:00 a.m. to 3:00 p.m.) the surplus is lost as the battery is fully charged. The travel stops at 5:00 p.m. with the battery charged to 92.48 percent. In Warsaw the panel power surplus appears from 10:45 a.m. until 1:15 p.m. and the battery charge is then equalized while running. The vehicle stops with the battery charged to 81.36 percent with the distance amounting to $540 \mathrm{~km}$.

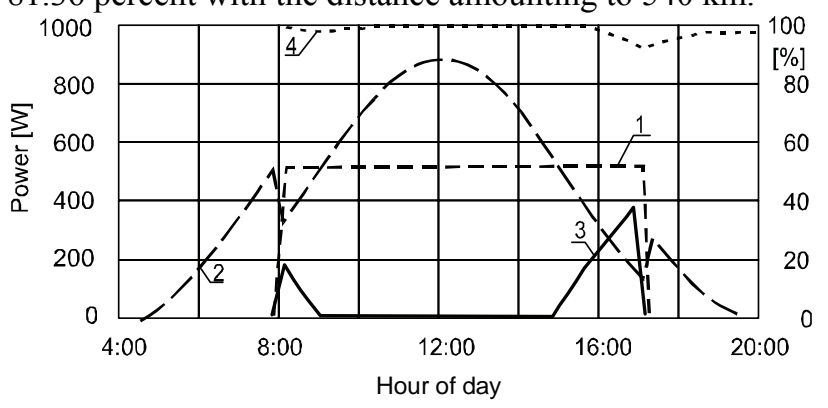

Fig. 10. Power balance of the solar car in Barcelona, Var. III; (1) - power demand; (2) - the power drawn from the panel; (3) - the power drawn from the battery; (4) - total battery discharge

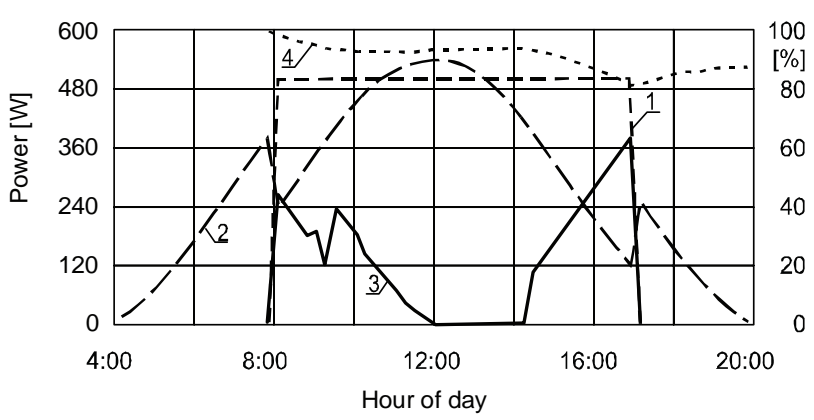

Fig. 11. Power balance of the solar car in Warsaw, Variant III; (1) - power demand; (2) - the power drawn from the panel; (3) - the power drawn from the battery; (4) - total battery discharge

Using the GaAs panels of high efficiency and lithium ion batteries in case of a car of the parameters $m=270$ $\mathrm{kg}, \mathrm{c}_{\mathrm{T}}=0.0025, \mathrm{c}_{\mathrm{A}}=0.1, \mathrm{v}=120 \mathrm{~km} / \mathrm{h}$ results in total power demand amounting to $2908.11 \mathrm{~W}$. The case is shown in Figures 12 and 13.

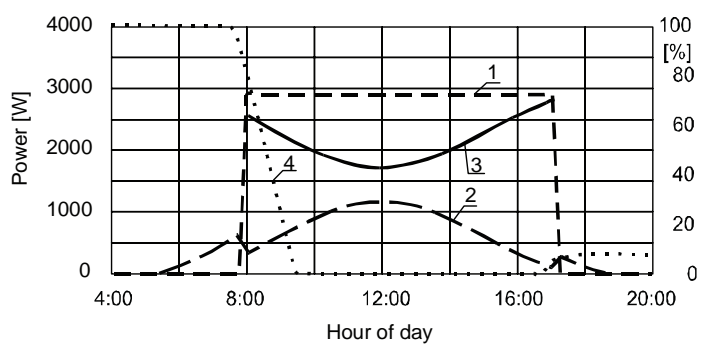

Fig. 12. Power balance of the solar car in Barcelona, Variant IV; (1) - power demand; (2) - the power drawn from the panel; (3) - the power drawn from the battery; (4) - total battery discharge

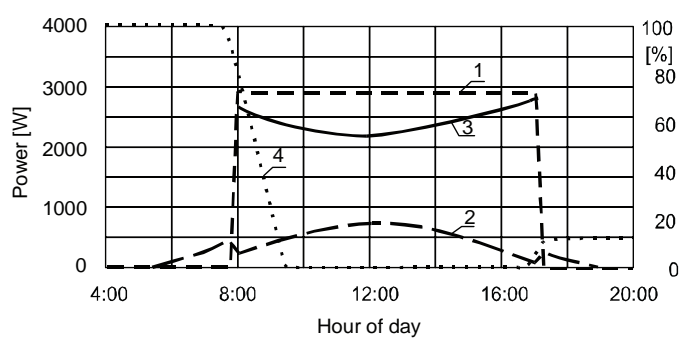

Fig. 13. Power balance of the solar car in Warsaw, Variant IV; (1) - power demand; (2) - the power drawn from the panel; (3) - the power drawn from the battery; (4) - total battery discharge 
In case of hight power demand, $9117,89 \mathrm{~W}\left(\mathrm{c}_{\mathrm{T}}=0.005\right.$, $\mathrm{A} \cdot \mathrm{c}_{\mathrm{A}}=0.2, \mathrm{~m}=330 \mathrm{~kg}, \mathrm{v}=140 \mathrm{~km} / \mathrm{h}$ ) and the use of CIS panel, the battery (lead-acid battery) is discharged almost immediately, as the panel covers several percent of total power demand (Variant V).

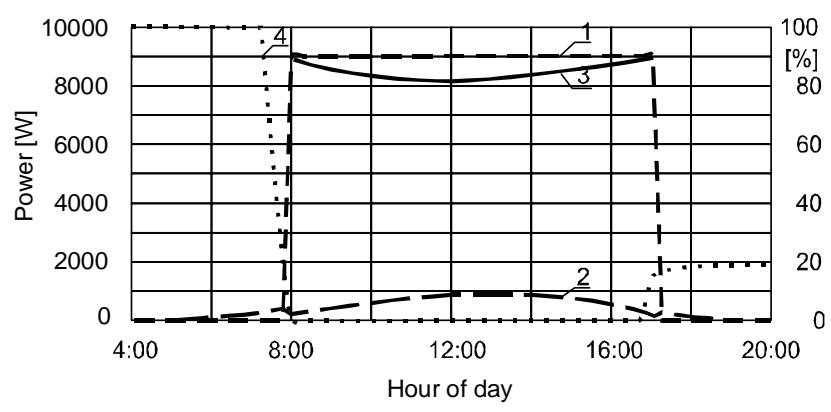

Fig. 14. Power balance of the solar car in Barcelona, Variant V; (1) - power demand; (2) - the power drawn from the panel; (3) - the power drawn from the battery; (4) - total battery discharge

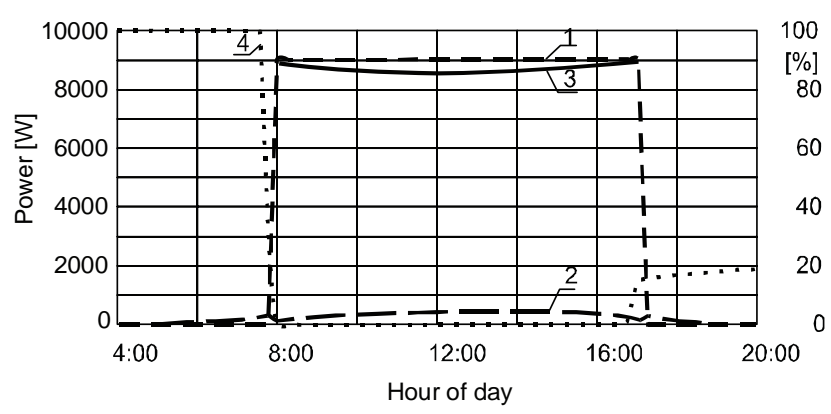

Fig. 13. Power balance of the solar car in Warsaw, Variant V; (1) - power demand; (2) - the power drawn from the panel; (3) - the power drawn from the battery; (4) - total battery discharge

The use of cadmium telluride CdTe at present appears unprofitable (the cell efficiency amounts to $16 \%$, Table 2). Nevertheless, the modules made of this material shall provide significant advantages in the future. Laboratory efficiency is estimated to above $30 \%$ [9].

Figure 15 shows an example relationship between the material used in the power panel of a vehicle and possible distance of its travel.

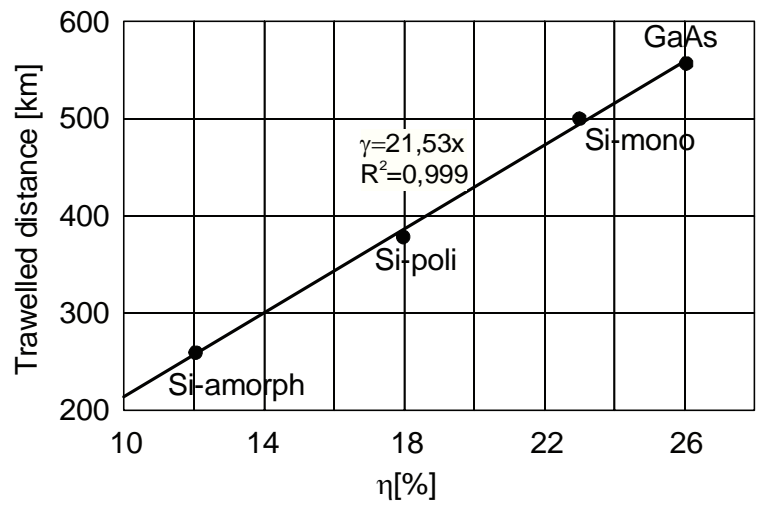

Fig. 15. Correlation between array efficiency and travel distance

Figure 16 shows the relationship between an example vehicle velocity and possible travel distance.

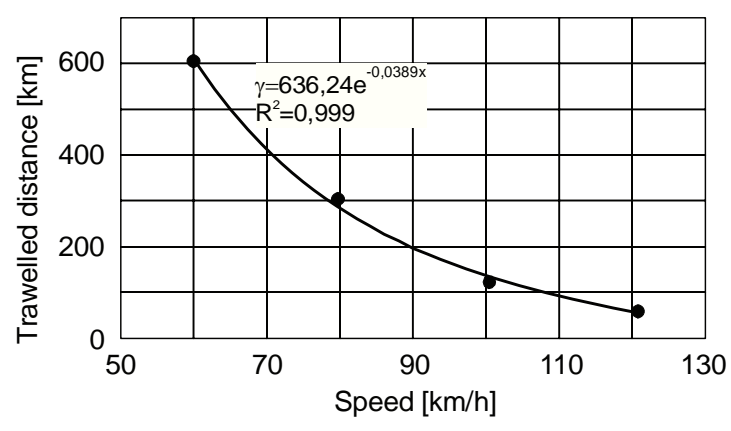

Fig. 16. Correlation between the velocity of solar car and its travelled distance

\section{Conclusions}

1. In Barcelona duration of power supply from the photovoltaic panel within a day is shorter than in Warsaw, but its value is higher. Longer daily insolation in Warsaw does not compensate higher power of the radiation in Barcelona, Table 1.

2. . The share of battery power in coverage of total power demand depends on the power gained from the PV panel (array, efficiency and arrangement of the panel), a geographical location of Barcelona and Warsaw and the insolation corresponding to these location). and the efficiency of the driving system.

3. The correlation between PV efficiency and travelled distance is linear, Fig. 14.

4. Use of GaAs PV panel comparing to $\mathrm{Si}$ amorphous increases the travelled distance of $115 \%$ and to monocrystalline silicon, of $47 \%$.

5. In Warsaw the battery may be charged from 4.00 a.m. and even till 8.00 p.m. in June, while in Barcelona only between 5.30 a.m. and 6.30 p.m.

6. In Warsaw the power to be gained from the battery in order to cover total power demand is higher than in Barcelona. In Variant I the supplementary battery power in Barcelona at 8:00 a.m. amounted to 64.8 percent, while at noon only 4.6 percent. On the other hand, in Warsaw these levels amounted to 74.1 and 40.8 percent, respectively.

7. In order to avoid the loss of the power surplus, as in Variant III, the operational conditions of the solar vehicle should be planned appropriately.

8. The power gained from photovoltaic conversion is higher while parking than while running, due to possible optimal arrangement of the panel. The stops should be planned in such time as to ensure the highest possible value of the difference between the parking and running modes. Taking into account that power loss of the battery may be estimated to 20 percent, parking of the vehicle is disadvantageous when the difference is below 25 percent. 
9. The best solution is travelling with highest speeds near midday and parking in the first and last hours of sunshine.

10. The correlation between the speed and travelled distance is exponential. For the speed $v=80 \mathrm{~km}$, relative decreasing of travelled distance is $50 \%$ to $v$ $=60 \mathrm{~km} / \mathrm{h}$.

11. The speed greater of $120 \mathrm{~km} / \mathrm{h}$ is almost useless (high discharge of battery). Better range of the vehicle may be obtained when running with lower speed within the whole planned time than in case of shortening the run due to battery discharge.

Optimal speed range for the described cases is between 40 and $80 \mathrm{~km} / \mathrm{h}$, eventually $100 \mathrm{~km} / \mathrm{h}$, Fig. 15.

12. Is truly important to reach the hoped results without underdischarge the battery.

13. In practice it is not recommended so called "deep discharge" of a battery. We should stop the journey earlier and charge the battery [12].

14. Optimization of one or more variables allons to increase the travelled distance.

15. In case of longer journeys another interesting solution of the problems seems to be a hybrid vehicle using sun energy $[1,3,9]$, a vegetable oil, powered combustion engine, the lithium - ionic accumulators, e.eg. the cobalt batteries in which the value of energy density is more than four times higher than in case of the conventional lead ones, (Connector, Honda EVN, Peugeot Concept BB1 4), or in electric cars for battery charging or air-conditioning supply.

\section{References}

[1] Arsie I.: A parametric study of the design variables for a hybrid electric car with solar cells. Metime 1st Intl. Conf. Thermal Engines and Environmental Engineering, University of Galati June 3-4, (2005), webcache.googleusercontent.com pp.1-11.
[2] Carroll D.R,: The Winning Solar Car. A Design Guide Warrendale USA Acnowledgement, SAE International (2003), pp. 15-49.

[3] Dixon J., Zuñiga A., Abuslerne A., Soto D.: Battery Powered Electric Car, Using Photovoltaic Cells Assistance, pp. 9-11 (www2.ing.puc.cl).

[4] Farret F.A., Simões M.G.: Integration of Alternative Sources of Energy, IEEE Wiley Interscience, New Jersey (2006), pp. 262-276.

[5] Frydrychowicz-Jastrzębska G., Szaferski M.: The effect of structural and operational parameters on running characteristics of a solar car, Przegląd Elektrotechniczny, (Electrotechnic Review) $\mathrm{N}^{0} 5$, (2007), pp. 36-38.

[6] Frydrychowicz-Jastrzębska G., Szaferski M.: Computer simulation of working characteristics of a solar vehicle depending on its parameters and external conditions, Monograph Computer Applications in Engineering, Poznań University of Technology, Poznań (2009), pp.367-378.

[7] Gołąbek S. Samochody słoneczne, (Solar cars) EKO AUTO Wrocław (2008), pp. 81-110.

[8] Goyal A., Khalaf R., Mehta A., Somani A., Somani P.: Solar Eclipse: The Failure of a Promising Technology, Solar Electric Vehicle Team (SEVT), December 15, 2000, pp. 1-26.

[9] Jastrzębska G.: Odnawialne źródła energii i pojazdy proekologiczne, (Renowable energy sources and proecological vehicles), Wydawnictwa NaukowoTechniczne, Warszawa (The Printing House WNT, Warsaw), (2009), pp. 200-217, 254-270.

[10]Kolano J.: Systemy fotowoltaiczne zasilające elektryczne układy napędowe, (PV modules supplying electrical driving systems) PAN, Elektrotechnika, (Polish Academy of Science), Lublin, (2002), pp. 56-80.

[11] Patel M.R.: Wind and Solar Power Systems, Design, Analysis and Operation, Taylor \& Francis Group, Boca Raton London, New York, Singapore, (2006), pp. 172180.

[12] Szumanowski A.: Akumulacja energii w pojazdach, Energy storage in vehicles), WKL, Warszawa,(The Printing House WKŁ, Warsaw), (1984), pp. 26-28.

[13] Wakefield E.H.: History of the Electric Automobile. Hybrid Electric Vehicles, SAE Warrendale, United States in America, (1998), pp. 175-304.

[14] http://www.speedace.info.solarcars//ashiya university_solar_car-project_japan.htm 